Big Bird and Beyond 



\section{BIG BIRD}

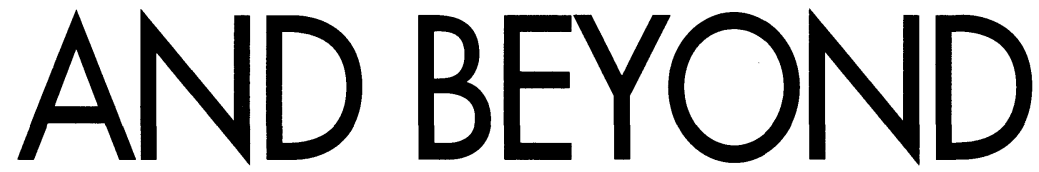

The New Media and the Markle Foundation

See D. Mitgang

FORDHAM UNIVERSITY PRESS

New York $\cdot 2000$ 
Copyright @ 2000 by Lee D. Mitgang

All rights reserved. No part of this publication may be reproduced, stored in a retrieval system, or transmitted in any form or by any means-electronic, mechanical, photocopy, recording, or any other-except for brief quotations in printed reviews, without the prior permission of the publisher.

\section{Library of Congress Cataloging-in-Publication Data}

Mitgang, Lee D., 1949-

Big Bird and beyong : the new media and the Markle Foundation / Lee D. Mitgang.-1st ed.

p. $\mathrm{cm}$.

Includes bibliographical references and index.

ISBN 0-8232-2040-0-ISBN 0-8232-2041-9 (pbk.)

1. John and Mary R. Markle Foundation-History. 2. Mass media-Research-United States-History. I. John and Mary R. Markle Foundation. II. Title.

P87.M55 2000

$384.55^{\prime} 06^{\prime} 573-\mathrm{dc} 21$

$00-027540$

Printed in the United States of America

$\begin{array}{llllllllll}00 & 01 & 02 & 03 & 04 & 5 & 4 & 3 & 2 & 1\end{array}$

First Edition 
For My Parents,

Herbert and Shirley Mitgang 
